\title{
Antifouling and toxic properties of the bioactive metabolites from the seagrasses Syringodium isoetifolium and Cymodocea serrulata
}

Palanisamy lyapparaj, Peranandam Revathi, Ramasamy Ramasubburayan, Santhiyagu Prakash, Arunachalam Palavesam, Grasian Immanuel, Perumal Anantharaman, Asmita Sautreau, Claire Hellio

Abstract

The present study documents the antifouling and toxic properties of seagrasses Syringodium isoetifolium and Cymodocea serrulata. For that, the seagrasses S. isoetifolium and C. serrulata were extracted individually using organic solvents viz. dichloromethane, acetone and methanol. Amongst the extracts, the maximum antimicrofouling and antimacrofouling activities were exhibited by methanol extracts of both the seagrasses. The Minimal Inhibitory Concentration (MIC) of methanolic extracts of seagrasses was ranged from 1.0 to 10 $\mathrm{mg} / \mathrm{ml}$ against test biofilm bacteria and microalgal strains. Similarly, $100 \%$ fouling inhibition of limpet Patella vulgata was found at $6.0 \mathrm{mg} / \mathrm{ml}$ of methanolic extracts of seagrasses. The mussel Perna indica showed $50 \%$ of byssal production and attachment inhibition at $21.51 \pm 2.03,17.82 \pm 1.07 \mu \mathrm{g} / \mathrm{ml}$ and the anticrustaecean activity for $50 \%$ mortality of Artemia salina was recorded at $732.14 \pm 9.21$ and $394.16 \pm 5.16 \mu \mathrm{g} / \mathrm{ml}$ respectively for methanolic extracts of $S$. isoetifolium and $C$. serrulata. The minimal inhibitory and higher lethal concentrations of active methanol extracts shows it's less toxic nature. Based on the prolific results, methanol extracts of $S$. isoetifolium and $C$. serrulata were subjected to purification using silica gel column and thin layer chromatography. Then the active compounds of the bioassay guided fractions were partially characterized using gas chromatography coupled with mass spectroscopy (GC-MS) and keyed out that fatty acids $\left(C_{16}\right.$ to $\left.C_{24}\right)$ were the major components which responsible for the antifouling properties of the candidate seagrasses.

\section{Introduction}

Marine biofouling, can be defined as the growth of unwanted organisms on the surface of artificial structures immersed in water (Yebra et al., 2004; Buma et al., 2009). Biofouling causes huge material and economic costs of maintenance of mariculture, naval vessels, and seawater pipelines (Yebra et al., 2004). It is estimated that governments and industry spend over US $\$ 6.5$ billion annually to prevent and control marine biofouling (Bhadury and Wright, 2004). Further, ecological implications of biofouling include increased carbon emission and potential dispersion of invasive alien species (Bellas, 2006; Floerl et al., 2009; Silkina et al., 2012). 
Antifouling is the process of controlling or mitigating the settlement of fouling organisms on a surface. Commercial antifouling techniques include mechanical cleaning, biocides, toxic antifouling coatings and foul release or easy clean coatings. Amongst the above, antifouling paints containing toxic chemicals are the main strategies against biofouling in the past. Tributyltin (TBT) was the most effective component in antifouling paints which was detrimental, not readily degraded in the natural environments and had non-targeted toxicity on organisms (Konstantinou and Albanis, 2004). This property has led the International Maritime Organisation (IMO) to prohibit its application to ships since 17 September 2008 (Qian et al., 2010). The substitutes of TBT, such as Irgarol 1051 and Diuron, have also been found to be harmful to many non-target organisms (Konstantinou and Albanis, 2004; Zhou et al., 2006).

Hence, alternative and environmentally acceptable, safe and effective antifouling substances are needed for incorporation into antifouling coatings, and these may include natural products isolated from certain marine organisms (Clare, 1996). Incorporation of natural repellent products into antifouling paints has been tried by some researchers (Armstrong et al., 2000; Peppiatt et al., 2000). For this, a wide range of marine natural products have been screened for their activity concerning antimicrobial, antifungal, antialgal and antilarval properties (reviewed by Clare, 1996; Fusetani, 2004; Dobretsov et al., 2006). Compounds with antifouling potential have been studied intensively in various marine sponges (Tsouletou et al., 2002; Hellio et al., 2005) and algae (De Nys et al., 1995; Maximilien et al., 1998; Sjogren et al., 2004).

Marine natural products or crude extracts with antifouling activity have been reported from many marine organisms including marine bacteria, seaweeds, seagrasses, bryozoans, ascidians, cnidarians and sponges (Pawlik, 1992; Clare, 1996; Rittschof, 2001).

Antifouling and biological activities of marine macrophytes have been extensively studied by many researchers in various species of mangroves (Chen et al., 2008), seaweeds (Silkina et al., 2012) and seagrasses (Mayavu et al., 2009; Prabhakaran et al., 2012). Seagrasses are a rich source of secondary metabolites, particularly phenolic compounds (McMillan et al., 1980). Seagrass phenolic compounds include sulfated flavonoids, a group of conjugated metabolites for which the sulfate component is believed to represent a marine adaptation (Harborne and Williams, 1976). Phenolic compounds are well known allelopathic agents present in terrestrial plants (Swain, 1977). In support of this suggestion, polyphenolic compounds have long been associated with reduced fouling in seaweeds (Jennings and Steinberg, 1997) and it has been proposed that eelgrass chemistry alters the composition of the epiphytic community (Harrison, 1982). In addition, the total concentration of phenolic compounds in Zostera marina was shown to increase in response to infection by Labyrinthula zostera (Vergeer et al., 1995), and a phenolic compound purified from this seagrass had antifouling activity (Todd et al. 1993). 
Considering the need for ecological safety and lack of information on natural antifouling compounds from marine flora, especially from seagrasses, the present work was undertaken to explore the antifouling, toxic properties of the seagrasses and also to investigate the bioactive constituents of Syringodium isoetifolium and Cymodocea serrulata.

\section{Materials and methods}

\subsection{Seagrasses}

For the present study, the following seagrass species were selected for being free of epibionts during visual examination. The fresh leaves of $S$. isoetifolium (Order: Potamogetonales, Family: Cymodoceaceae) and $C$. serrulata (Order: Potamogetonales, Family: Cymodoceaceae) were collected from the Arockiapuram coast (Lat $8^{\circ} 06^{\prime} 46.1^{\prime \prime}$ Long $77^{\circ} 33^{\prime} 21.9^{\prime \prime}$ ) of Kanyakumari District, Tamilnadu, India.

\subsection{Extraction}

Collected seagrasses were washed thoroughly with sterile seawater to remove the extraneous dirt and 3\% ethanol (97\% distilled water: $3 \%$ ethanol) was used to wipe off the epiphytes. Then the seagrasses were dried well in an incubator at $301 \mathrm{C}$ and finely powdered using electrical grinder. Hundred grams of each seagrass powder were extracted individually in $500 \mathrm{ml}$ organic solvent, including dichloromethane, acetone and methanol. Extraction was done in darkness, at room temperature: $20 \pm 2{ }^{\circ} \mathrm{C}$. The process was repeated thrice; extracts were pooled and filtered through Whatmann no. 1 filter paper. Each filtrate was dried under reduced pressure using a rotary evaporator. Dried extracts were weighed and stored in screw cap vials for further study.

\subsection{Test organisms}

Antimicrofouling activity of seagrass extracts were tested against 10 biofilm bacteria such as Pseudomonas aeruginosa JN979983, Halomonas aquamarina JN561698, Vibrio alginolyticus JN979984, Pantoea agglomerans JN979985, Serratia marcescens JN596118, Serratia liquefaciens JN596115, Vibrio fischeri JN979986, Vibrio parahaemolyticus JN585666, Shigella flexneri JN979987 and Aeromonas hydrophila JN561697 collected from the microbial culture collections of Centre for Marine Sciences and Technology, Manonmaniam Sundaranar University, Rajakkamangalam, Tamilnadu, India. To screen the antimicroalgal activity, five fouling microalgal strains such as Pleurosigma elongatum CASMB 001, Thalassiothrix frauenfeldii CASMB 002, Nitzschia sigma CASMB 003, Navicula longa CASMB 004 and Astreonellopsis glacialis CASMB 005 
were collected from the microalgal culture collections of CAS in Marine Biology, Annamalai University, Tamilnadu, India. The antimacrofouling property of the seagrass extracts was screened using the limpet Patella vulgata and brown mussel Perna indica. These animals were collected from the rocky surfaces of Manavalakurichi coast, (Lat. $8^{\circ} 8^{\prime} 35^{\prime \prime}$ and Long. $77^{\circ} 8^{\prime} 00^{\prime \prime}$ ), Kanyakumari District, Tamilnadu, India. For cytotoxicity assay, the brine shrimp Artemia salina was hatched out from the cysts (San Fransisco Bay, NC, USA).

\subsection{Antimicrofouling activity}

\subsubsection{Antibacterial assay}

Antibacterial activity of seagrass extracts was assessed by following the method of Marechal et al. (2004). The assay was started with the inoculation of the same density of bacteria $\left(2.10^{8}\right.$ cells $\left./ \mathrm{ml}\right)$ using the table of Amsterdam (1996). $100 \mu$ l of each seagrass extract with the concentrations of $0.01,0.1,1.0,10,25,50$ and $100 \mu \mathrm{g} / \mathrm{ml}$ were poured individually in 6 wells of 96 wells plate for each bacterial assay. In addition, 6 wells free of extracts were used as a control. These plates were dried under UV chamber for $2 \mathrm{~h}$ to evaporate the solvent under sterile condition. $100 \mathrm{ml}$ of the bacterial suspension were then added under aseptic conditions and the plates were incubated at $30^{\circ} \mathrm{C}$ for $48 \mathrm{~h}$ to allow the bacterial growth. One plate was used for each test bacterium to decrease the risk of contamination. The least concentration of extract where no turbidity was observed in at least 4 of the 6 wells was noted as the minimum inhibitory concentration (MIC).

\subsubsection{Anti-microalgal assay}

Similar to the antibacterial assay, anti-microalgal assay was also conducted with the same test concentrations of seagrass extracts using 96 well plates and the assay was started with the initial cell density of $1.0 \times 10^{5}$ cells $/ \mathrm{ml}$. Then the plates were incubated under 20 lux light at $20^{\circ} \mathrm{C}$ for $120 \mathrm{~h}$. The least concentration of extract where no algal growth was observed in at least 4 of the 6 wells was recorded as the minimum inhibitory concentration (MIC) (Thabard et al., 2009). Based on the results, the methanolic extracts of both seagrass were selected for further study.

\subsection{Antimacrofouling activity}

\subsubsection{Mollusc foot adherence assay}

$P$. vulgata is a common fouling organism found on rocky shores. The mollusc foot adherence assay is a rapid and reliable assay that requires a minimum quantity of test extract to determine its effect on the settlement of mollusc $P$. vulgata by spreading and shrinking of the foot. The assay was done in triplicate as per the method of Selvin and Lipton (2002) to determine the fouling (\%) and regaining (\%) ability of limpet $P$. vulgata 
against methanolic extracts of $S$. isoetifolium and $C$. serrulata using $1.0-6.0 \mathrm{mg} / \mathrm{ml}$ concentrations. The seawater without extract was used as the control.

\subsubsection{Mussel bioassay}

Mussels are one among the major fouling organisms that come under the category of hard fouling. In this context, a mussel bioassay was done by following the method of Wilsanand et al. (1999) and Murugan and Santhana Ramasamy (2003) using the brown mussel $P$. indica to explore the antifouling property of seagrass extracts. Test concentrations of seagrass extracts $(0.1,1.0,10,25,50,100,200$ and $400 \mu \mathrm{g} / \mathrm{ml})$ were selected and the seawater without extract was used as the control. The assay was performed in triplicate. After $24 \mathrm{~h}$, the $\mathrm{EC}_{50}$ (effective concentration for $50 \%$ inhibition of byssal production) and at $96 \mathrm{~h}, \mathrm{LC}_{50}$ (lethal concentration for $50 \%$ mortality) were also estimated through probit analysis. $\mathrm{The}^{\mathrm{L}} \mathrm{C}_{50} / \mathrm{EC}_{50}$ ratio of seagrass extracts was also calculated to assess the non-toxic property.

\subsubsection{Anticrustacean assay}

Anticrustacean assay is a simplest screening technique to study the repelling effects of bioactive compounds against the crustaeceous fouling organisms using Artemia as the model organism. The cysts of brine shrimp (A. salina) were hatched in a conical vessel $(1 \mathrm{~L})$ filled with filtered seawater under constant aeration for 24-48

h. Ten active larvae (I instar) were collected from a brighter portion of the hatching chamber by using a capillary glass tube and placed in a test tube containing $10 \mathrm{ml}$ of brine solution with varying concentrations (5, $10,25,50,100,250,500$, and $1000 \mu \mathrm{g} / \mathrm{ml}$ ) of crude extract of selected seagrasses. Seawater without extract was kept as control and maintained at room temperature for $24 \mathrm{~h}$ under light. After $24 \mathrm{~h}$ of exposure, the number of larvae surviving in each test concentration was counted and the $\mathrm{LC}_{50}$ values were analyzed by probit analysis and the percentage of larval mortality was calculated (Meyer et al., 1982).

\subsection{Chemistry of antifouling compounds}

\subsubsection{Fractionation}

Potentially bioactive methanolic extracts $(20 \mathrm{~g})$ of each seagrass (S. isoetifolium and $C$. serrulata) were individually fractionated and purified with an Ace chromatography column $(5.0 \mathrm{~cm}$ diameter $x 61 \mathrm{~cm}$ length) filled with silica gel (60-200 $\mu \mathrm{m}$ mesh size) using elution gradiant of hexane $\left(\mathrm{C}_{6} \mathrm{H}_{14}\right)$, chloroform $\left(\mathrm{CHCl}_{3}\right)$ and methanol $(\mathrm{MeOH})$. Twenty seven fractions $(150 \mathrm{ml})$ were collected separately in a step gradient elution starting with $100 \%$ hexane and ending with $100 \%$ warmed methanol. All the fractions were individually tested for bioactivity and the seventh fraction $\left(\mathrm{CHCl}_{3} 75 \%\right.$ : $\left.\mathrm{MeOH} 25 \%\right)$ of both the extracts exhibited antifouling potencies. The bioassay guided column fractions were then subjected to thin layer chromatography (Merck, TLC Silica gel $F_{254}$ ) and visualized under UV chamber ( 282 and $326 \mathrm{~nm}$ ) as well with $p$-anisaldehyde stain then the $R_{f}$ values of the active compounds were documented. 


\subsubsection{Partial characterization}

The GC_MS analysis of bioassay guided fractions of seagrass S. isoetifolium and C. serrulata were conducted individually using an Agilent GC_MS 5975 Inert XL MSD (United States) gas chromatography equipped with J\&W 122-5532G DB-5ms $30 \times 0.25 \mathrm{~mm}^{2} 0.25 \mu \mathrm{m}$ and mass detector (EM with replaceable horn) was operated in EMV mode. Helium was used as carrier gas with the flow rate of $1.0 \mathrm{ml} \mathrm{min}^{-1}$. The injection port temperature was operated at $250^{\circ} \mathrm{C}$. The column oven temperature was held at $80^{\circ} \mathrm{C}$ for $2 \mathrm{~min}$ then programmed at $10{ }^{\circ} \mathrm{C} \mathrm{min}^{-1}$ to $250{ }^{\circ} \mathrm{C}$ which was held for $0 \mathrm{~min}$, and then at $5^{\circ} \mathrm{C} \mathrm{min}^{-1}$ to $280{ }^{\circ} \mathrm{C}$ which was held for $9 \mathrm{~min}$. Electron impact spectra in positive ionization mode were acquired between $\mathrm{m} / \mathrm{z} 50$ and 550 . For more accuracy, the peaks with prominent area and quality $(>70 \%)$ were alone considered and the constituents were identified by comparison with the internal standards of the instrument and spectral match with NIST library.

\subsection{Statistical analysis}

The data were analyzed using SPSS Version 16.0 software package. The differences between the experiment and control samples were determined using one-way ANOVAs followed by Dunnett's test at $95 \%$ confidence level for all antimacrofouling assays. Using probit analysis, the EC50 (concentration at which $50 \%$ of the inhibition of byssal production in mussel compared with the control) and LC50 (concentration at which $50 \%$ of mussels and artemia naupli were dead compared with the control) values of the mussel and anticrustaecean bioassays were calculated respectively.

\section{Results}

\subsection{Antimicrofouling activities}

\subsubsection{Antibacterial assay}

Extracts of $C$. serrulata and S. isoetifolium were found to inhibit the growth of test bacteria. Among the tested solvents, the methanolic extract of $C$. serrulata and $S$. isoetifolium showed better inhibitory activity compared with other solvents against the biofilm bacteria and the MIC was $1.0 \mu \mathrm{g} / \mathrm{ml}$ (Table 1). 


\section{Table 1}

Antimicrofouling activities and minimum inhibitory concentration of seagrass extracts.

\section{Biofilm bacteria}

\begin{tabular}{|c|c|c|c|c|c|c|}
\hline & $(\mu \mathrm{g} /$ & & & $(\mu \mathrm{g}$ & & \\
\hline & $\mathrm{D}$ & $A$ & $\mathrm{M}$ & $\mathrm{D}$ & $A$ & $\mathrm{M}$ \\
\hline P. aeruginosa JN979983 & 10 & 25 & 1.0 & 10 & 25 & 10 \\
\hline H. aquamarina JN561698 & 10 & 25 & 10 & 25 & 50 & 1.0 \\
\hline V. alginolyticus JN979984 & 25 & 50 & 25 & $\mathrm{NI}$ & $\mathrm{NI}$ & 10 \\
\hline P. agglomerans JN979985 & 25 & $\mathrm{NI}$ & 1.0 & 25 & 25 & 1.0 \\
\hline S. marcescens JN596118 & 10 & 25 & 10 & 10 & 50 & 1.0 \\
\hline S. liquifaecians JN596115 & 50 & 50 & 10 & 50 & 10 & 10 \\
\hline V. fischeri JN979986 & 10 & $\mathrm{NI}$ & 10 & 10 & 25 & 1.0 \\
\hline V. parahaemolyticus JN585666 & $\mathrm{NI}$ & 50 & 25 & 25 & 50 & 10 \\
\hline S. flexneri JN979987 & 25 & 25 & 1.0 & 25 & 50 & 25 \\
\hline A. hydrophila JN561697 & 10 & 50 & 10 & 10 & $\mathrm{NI}$ & 1.0 \\
\hline
\end{tabular}

\section{Microalgal strains}

$\begin{array}{lllllll}\text { P. elongatum CASMB 001 } & 50 & 25 & 10 & 25 & 25 & 10 \\ \text { T. frauenfeldii CASMB 002 } & 10 & 50 & 25 & 50 & 10 & 1.0 \\ \text { N. sigma CASMB } 003 & \mathrm{NI} & 10 & 1.0 & \mathrm{NI} & 25 & 10 \\ \text { N. longa CASMB 004 } & 50 & 50 & 25 & 50 & 10 & 25 \\ \text { A. glacialis CASMB } 005 & 25 & 25 & 10 & 25 & 50 & 10\end{array}$

Each value is obtained from 6 replicates; D: dichloromethane; A: acetone; M: methanol NI: no inhibition.

\subsubsection{Anti-microalgal assay}

Extracts of $C$. serrulata and S. isoetifolium were also found to inhibit the growth of test microalgae. However, MIC of $10 \mu \mathrm{g} / \mathrm{ml}$ for test microalgae was recorded by methanolic extract of S. isoetifolium. Anti-microalgal activity of methanolic extract of $C$. serrulata was observed at $1.0 \mu \mathrm{g} / \mathrm{ml}$ (Table 1 ). The results implied that the methanolic extracts exhibited better antimicrofouling activities than the acetone and dichloromethane extracts. 


\subsection{Antimacrofouling activities}

\subsubsection{Mollusc foot adherence assay}

During this assay, the percentage of fouling by limpet $P$. vulgata was decreased with subsequent increase in the concentration of seagrass extract from 1.0 to $6.0 \mathrm{mg} / \mathrm{ml}$. Methanolic extracts of $S$. isoetifolium and $C$. serrulata showed $0 \%$ fouling (100\% inhibition) at $6.0 \mathrm{mg} / \mathrm{ml}$ with $48.83 \pm 2.05$ and $45.6 \pm 3.52 \%$ of limpet regaining their function when transferred to fresh seawater. The regaining ability and the behavioral changes such as spreading, shrinking, and attachment of the foot of $P$. vulgata was disturbed with increase in the concentration of seagrass extracts (Figs. 1 and 2). The variation in percentage of fouling and regaining of $P$. vulgata due to the concentration of seagrass extracts was statistically significant $(P<0.05-0.0001)$.

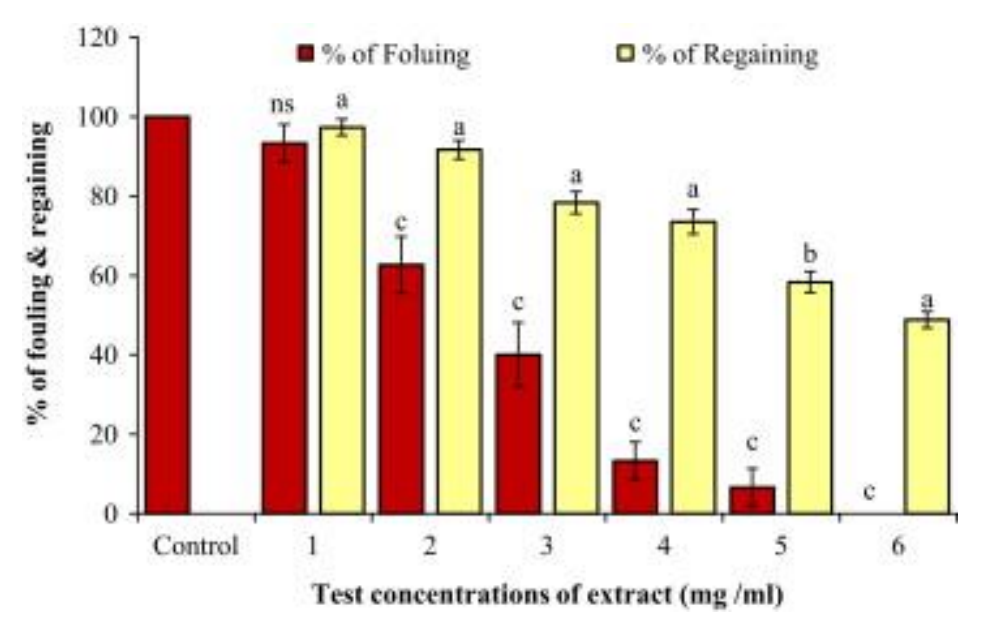

Fig. 1. Percentage of fouling and regaining of $P$. vulgata due to methanolic extract of $S$. isoetifolium. Each values are the mean \pm SD of three observations. (a) $\mathrm{P}<0.05$; (b) $\mathrm{P}<0.001$; and (c) $\mathrm{P}<0.0001$ significant; ns: non-significant.

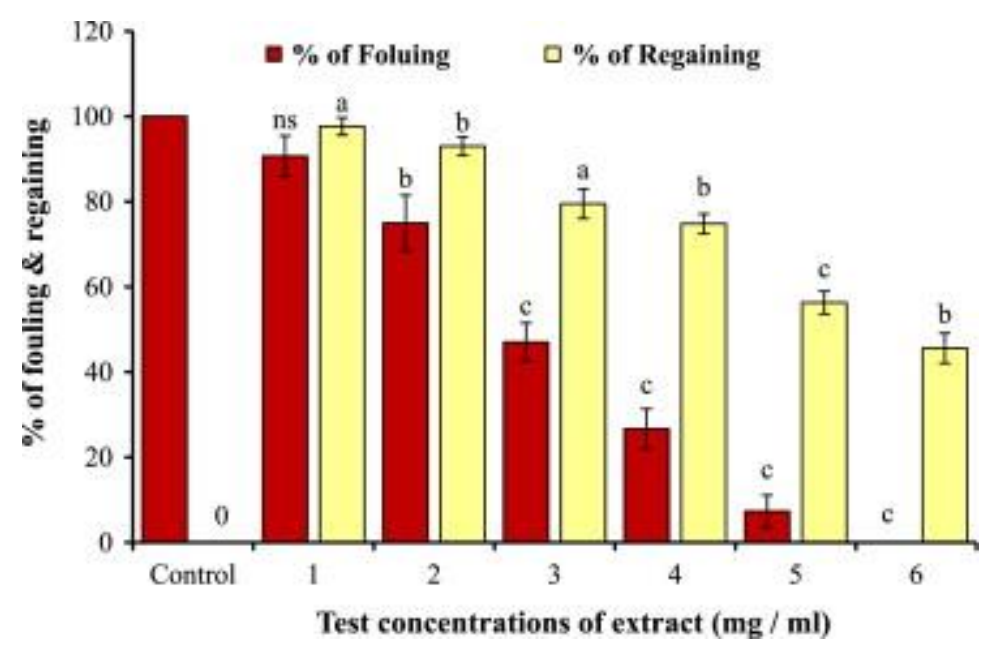

Fig. 2. Percentage of fouling and regaining of $P$. vulgata due to methanolic extract of $C$. serrulata. Each values are the mean \pm SD of three observations. (a) $P<0.05$; (b) $P<0.001$; and (c) $P<0.0001$ significant; ns: non-significant. 


\subsubsection{Mussel bioassay}

The effective concentration $\left(\mathrm{EC}_{50}\right)$ in which $50 \%$ inhibition of byssal production and attachment for brown mussel $P$. indica was observed and the lethal concentration $\left(L_{50}\right)$ represented $50 \%$ mortality of mussels. The $\mathrm{EC}_{50}$ values were $21.51 \pm 2.03$ and $17.82 \pm 1.07 \mu \mathrm{g} / \mathrm{ml}$ at $24 \mathrm{~h}$ for the methanolic extract of $S$. isoetifolium and C. serrulata respectively. The $\mathrm{LC}_{50}$ values of $336.5 \pm 3.12$ and $293.2 \pm 2.46 \mu \mathrm{g} / \mathrm{ml}$ were recorded during $72 \mathrm{~h}$ of experiment for the methanolic extract of $S$. isoetifolium and $C$. serrulata respectively. The $\mathrm{LC}_{50} / \mathrm{EC}_{50}$ ratios of $S$. isoetifolium and C. serrulata extracts were 16.45 and 15.64 (Table 2).

Table 2

$\mathrm{EC}_{50}$ and $\mathrm{LC}_{50}$ values of seagrass extracts during mussel bioassay.

$\begin{array}{llll}\text { Seagrass } & { }^{\mathrm{a}} \mathrm{EC}_{50}(\mu \mathrm{g} \mathrm{ml} \mathrm{1)} & { }^{\mathrm{a} L C_{50}}(\mu \mathrm{g} \mathrm{ml} 1) & \mathrm{LC}_{50} / \mathrm{EC}_{50} \\ \text { S. isoetifolium } & 21.51 \pm 2.03 & 336.5 \pm 3.12 & 15.64 \\ \text { C. serrulata } & 17.82 \pm 1.07 & 293.2 \pm 2.46 & 16.45\end{array}$

a Are the mean \pm SD of three observations.

\subsubsection{Anticrustacean assay}

Brine shrimp, Artemia salina larvae was used as a model organism to test the cytotoxic properties of selected seagrass extracts. The results indicated that the cytotoxicity of methanolic extracts of both the seagrasses were minimal with the $\mathrm{LC}_{50}$ values of $732.14 \pm 9.21$ and $394.16 \pm 5.16 \mu \mathrm{g} / \mathrm{ml}$ respectively. Besides, the percentage mortality of $A$. salina larvae was significantly $(P<0.05)$ increased along with the hike in test concentration of extracts (Fig. 3).

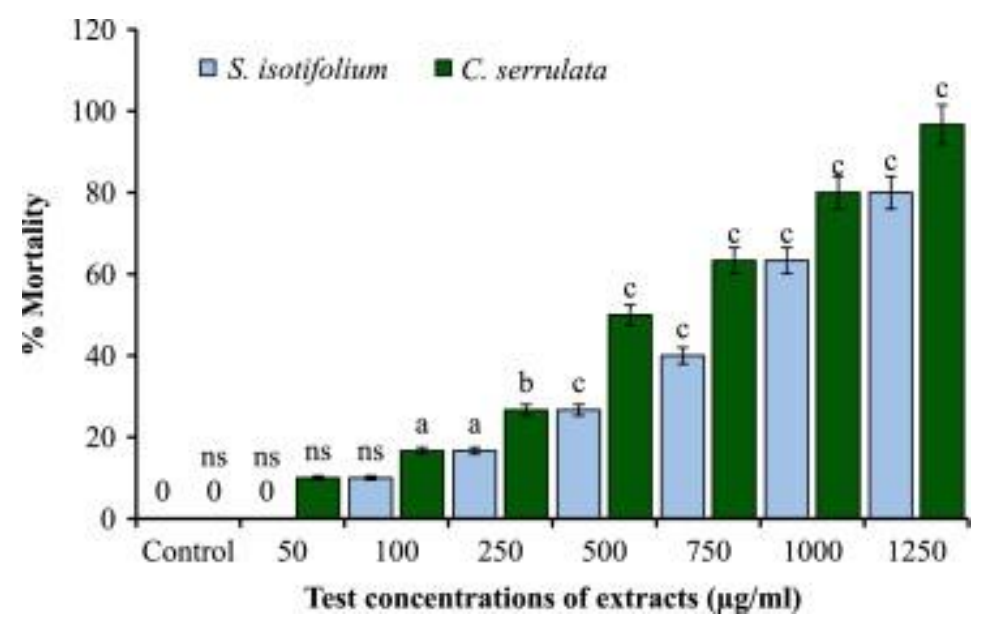

Fig. 3. Anticrustacean activity of methanolic extract of seagrasses. Each values are the mean \pm SD of three observations. (a) $P<0.05$; (b) $P<0.001$; and (c) $P<0.0001$ significant; ns: non-significant. 


\subsection{Chemistry of antifouling compounds}

\subsubsection{Column chromatography}

In total, 27 column fractions (150 ml/fraction) were collected individually for both the seagrass extracts and evaporated under vacuum. Then the fractions were transferred to preweighed, labeled vials and tested for antifouling activity. Among the column fractions, the seventh fraction $\left(\mathrm{CHCl}_{3} 75 \%\right.$ : $\left.\mathrm{MeOH} 25 \%\right)$ of $S$. isoetifolium weighing $356.2 \mathrm{mg}$ and C. serrulata weighing $332.7 \mathrm{mg}$ were expressed better antifouling activity against the test organisms.

Distribution and pattern of compounds present in the bioassay guided fractions were documented by silica gel thin layer chromatography. The bioassay guided fraction of $S$. isoetifolium recorded five compounds with the $R_{f}$ values of $0.40,0.52,0.68,0.89$ and 0.96 . Similarly, the active column fraction of $C$. serrulata registered six compounds with the $R_{f}$ values of $0.48,0.55,0.60,0.70,0.88$ and 0.92 .

\subsubsection{Partial characterization}

GC-MS chromatogram of the bioassay guided column fraction of $S$. isoetifolium showed the presence of five major peaks. The respective retention times $\left(R_{t}\right)$ of individual peaks recorded were 0.00-16.050, 0.00-17.531, 0.00-20.651, 0.00-20.778 and 0.00-27.960 $\mathrm{min}$. The major phycoconstituents observed in the active fraction were 2-pentadecanone, 6,10,14-trimethyl, hexadecanoic acid methyl ester, 9, 12-octadecadienoic (Z,Z)methyl ester, 9,12,15-octadecatrienoic acid methyl ester (Z,Z,Z) and 1,2-benzenedicar-boxylic acid diisooctyl ester

However, GC-MS analysis of bioassay guided column fraction of $C$. serrulata displayed six major peaks with respective retention time $\left(R_{t}\right)$ ranges viz. 0.00-16.017, 0.00-16.534, 0.00-21.109, 0.00-27.898, 0.00-30.149 and 0.00-30.283 $\mathrm{min}$. Thus, the active fraction unveiled the presence of 2-pentadecanone, 6,10,14-trimethyl, 1,2benzenedicarboxylic acid butyl 1,2-methylpropyl ester, octa-decanoic acid methyl ester, 1,2benzenedicarboxylic acid diisooctyl ester, oleic acid and erucic acid (Table 3). 
Table 3

Bioactive components in bioassay guided column fractions of selected seagrasses.

RT

Name of the compound

16.050 2-Pentadecanone, 6,10,14-trimethyl

17.531 Hexadecanoic acid methyl ester

20.651 9,12-Octadecadienoic (Z,Z)-methyl ester

20.778 9,12,15-Octadecatrienoic acid methyl ester $(Z, Z, Z)$

27.960 1,2-Benzenedicarboxylic acid diisooctyl ester

16.534 1,2-Benzenedicarboxylic acid, butyl 1,2-methylpropyl

21.109 Octadecanoic acid methyl ester

30.149 Oleic acid

30.283 Erucic acid
Molecular formula

\section{Molecular weight}

\section{S. isoetifolium $\quad$ C. serrulata}

Peak area (\%) Quality (\%) Peak area (\%) Quality (\%)

$\begin{array}{llllll}\mathrm{C}_{18} \mathrm{H}_{36} \mathrm{O} & 268.4 & 2.82 & 99 & 9.76 & 91\end{array}$

$\mathrm{C}_{17} \mathrm{H}_{34} \mathrm{O}_{2} \quad 270.4 \quad 4.32 \quad 98$

$\mathrm{C}_{19} \mathrm{H}_{34} \mathrm{O}_{2} \quad 294.4 \quad 11.31 \quad 97$

$\mathrm{C}_{19} \mathrm{H}_{32} \mathrm{O}_{2} \quad 292.4 \quad 6.90 \quad 95$

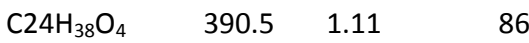

$5.77 \quad 87$

$4.35 \quad 86$

2.6490

$3.45 \quad 70$

$15.68 \quad 94$

\section{Discussion}

As the usage of conventional antifoulants is restricted, the search towards the identification of new alternative antifouling compounds with satisfactory performance and nonpolluting nature retain growing interest (Hellio et al., 2009; Dafforn et al., 2011). Since many sessile marine organisms have developed efficient defense mechanisms against microbial epibionts, there is an increasing interest in such organisms as a source of naturally released antifouling substances (Hellio et al., 2001; Bazes et al., 2006, 2009; Marechal and Hellio, 2009; Dafforn et al., 2011; Silkina et al., 2012). Seagrasses are the submerged and sessile marine angiosperms are found to resist the attachment of epibionts.

In the present study, methanolic extracts of seagrasses such as S. isoetifolium and C. serrulata were found to show better antifouling activity by inhibiting the growth of biofilm bacteria and microalgae with the MIC's of 1.0 and $10 \mu \mathrm{g} / \mathrm{ml}$ respectively which were better than the MIC's of 50 and $200 \mu \mathrm{g} / \mathrm{ml}$ recorded by Enhalus acoroides against bacteria (Qi et al., 2008). Supportively, Mayavu et al., (2009) reported the antibacterial activity of crude extracts (ethanol, methanol, acetone and dichloroethane) of seagrasses. Amongst that, ethanol and methanol extracts of $S$. isoetifolium and $C$. serrulata exhibited antagonistic activity against the bacteria isolated from boat hulls.

The limpet $P$. vulgata adheres firmly to rocky surfaces or other hard substrata using the broad, flat gray-green foot and can cause extensive fouling and biodeterioration of submerged structures. The fouling inhibition in $P$. vulgata by a methanolic extract of the sea cucumber Holothuria scabra was found at $4.2 \mathrm{mg} / \mathrm{ml}$ concentration 
(Selvin and Lipton, 2002). Accordingly, in the present study the seagrass extracts showed $100 \%$ fouling inhibition at $4.0 \mathrm{mg} / \mathrm{ml}$ concentration.

Mussels often close their shells and secrete fewer byssal threads with increasing concentration of the active extract and this may be an important criterion in improving the survivability and loss of attachment of mussels to the substrata during the experiment (Wilsanand et al. 1999). Hellio et al. (2000a, 2000b) reported inhibition of fouling organisms such as bacteria, fungi and mussels with less toxicity level by the extracts of brown algae Sargassum muticum and red algae Polysiphonia lanosa. The methanolic extract of Sargassum wightii at 205 $\mu \mathrm{g} / \mathrm{ml}$ concentration $\left(\mathrm{EC}_{50}\right.$ ) inhibited the byssal production and attachment of mussel $P$. indica (lyapparaj et al., 2012).

Methanolic extracts of $S$. isoetifolium and $C$. serrulata inhibited the byssal production and attachment at the EC50 concentrations of 21.51 and $17.82 \mu \mathrm{g} / \mathrm{ml}$ respectively. These $\mathrm{EC}_{50}$ values were better than our previous report on antimussel potentials of $S$. wightii (lyapparaj et al., 2012). The $\mathrm{LC}_{50} / \mathrm{EC}_{50}$ ratio is also known as therapeutic ratio, which is a common yardstick to measure the efficacy of a compound or extract. This ratio $>50$ are often considered as non-toxic, a much higher $\mathrm{LC}_{50} / \mathrm{EC}_{50}$ ratio is highly recommended when selecting candidate compounds or the extracts for further study (Qian et al., 2010). Nevertheless, the $\mathrm{LC}_{50} / \mathrm{EC}_{50}$ ratio of the S. isoetifolium and C. serrulata extracts were found to be $<50$. Despite the fact, lyapparaj et al. (2013) reported that the cellular level and biochemical changes in mussel $P$. indica due to the toxicity of methanolic extract of S. isoetifolium was lower than TBT.

The cytotoxicity of the seagrass extracts was estimated by anticrustacean assay using $A$. salina. This assay also used to evaluate the bioactivity of extracts against marine fouling organisms, especially the crustaceous foulers like barnacles (Persoone and Castritsi-Catharios, 1989). The methanolic extracts of S. iso-etifolium and C. serrulata recorded a low cytotoxic property with the higher LC50 values of $732.14 \pm 9.21$ and $394.16 \pm 5.16$ $\mu \mathrm{g} / \mathrm{ml}$ respectively. The above results are consistent with the findings of Prabhadevi et al. (1998) and Ragupathi Raja Kannan et al. (2013).

Only a few studies have been done on the bioactivity of seagrass and showed that seagrasses such as Thalassia testudinum, Posidonia oceanica and Z. marina had antibacterial (Harrison and Chan 1980, Devi et al., 1997a, Bhosale et al., 2002), antialgal (Harrison, 1982), antifungal (Jensen et al., 1998), antiviral (Premanathan et al., 1992), anti-inflammatory (Hua et al., 2006), toxicity (Devi et al., 1997b) and antifouling (Bhosale et al., 2002) activities. Chemical constituents of several seagrasses have also been described, including one antibiotic flavone glycoside from T. testudinum (Jensen et al., 1998), one sugar derivative from Ruppia maritima L. (Aquino et al., 2005), phenolic compounds from P. oceanica (Todd et al., 1993, Bushmann 
and Ailstock, 2006), diterpenes from R. maritima (Della Greca et al., 2000), and steroids and fatty acids from Zostera japonica (Gillan et al., 1984; Sanina et al., 2004; Hua et al., 2006).

GC-MS analysis of bioassay guided fractions of $S$. isoetifolium and C. serrulata showed the presence of 10 lipidic metabolites i.e. fatty acids and it's esters. In agreement with the present findings, Ragupathi Raja Kannan et al. (2012) also reported the fatty acid and it's esters as bioactive compounds from the candidate seagrasses. Similarly, the lipidic metabolites like fatty acids and galactoglycer-olipids from the seaweed S. muticum reported to have antifouling potential (Poluguerne et al., 2010).

These bioactive compounds have been described to possess antimicrobial properties when derived from plants. Wagh et al. (2006) reported the antibacterial and antifungal activity of hexadecanoic acid methyl ester, 9,12-octadecadienoic acid methyl ester and octadecanoic acid methyl ester. Yayli et al. (2005) evidenced the antibacterial and antifungal activity of 2-pentadecanone 6,10,14-trimethyl. An antimicrobial property of 1,2benzenedicarboxylic acid diisooctyl ester was described by Hema et al. (2011); however, in the present study, one of its esters 1,2-benzenedicarboxylic acid, bis (1,2- methylpropyl) ester also exhibited antifouling activity. Khoobchandani et al. (2010) reported the antibacterial activity of oleic and erucic acid. Similarly, 9,12,15octadecatrienoic acid was exhibited antibacterial and antifungal activities (Arunkumar and Muthuselvam, 2009).

The bioactive metabolites of seagrasses $S$. isoetifolium and $C$. serrulata may responsible for the antifouling activity. Hence, these seagrasses could be used as a source in the search for an alternate and safe remedy to biofouling. Further research on the individual chemical characterization of the antifouling metabolites using LC-MS and NMR is being directed in our laboratory. Also, field validation of the isolated bioactive components is needed. Testing the physical and chemical stability of these bioactive compounds with paint components will pave the way for the development of eco-friendly antifouling coatings.

\section{Acknowledgment}

The authors of this article would like to express their sincere thanks to University Grants Commission (UGC), India for the financial support through Dr. D. S. Kothari Post Doctoral Fellowship Scheme. 


\section{References}

Amsterdam, D., 1996. Susceptibility testing of antimicrobials in liquid media. In: Loman, V. (Ed.), Antibiotics in Laboratory Medicine, 4th ed. Williams and Wilkins, Baltimore, MD, pp. 52-111

Aquino, R.S., Landeira-Fernandez, A.M., Valente, A.P., Andrade, L.R., Moura, P.A.S., 2005. Occurrence of sulfated galactans in marine angiosperms: evolutionary implications. Glycobiology 15, 11-20.

Armstrong, E., Boyd, K.G., Pisacane, T., Peppiat, C.J., Burgess, J., 2000. Marine microbial natural products in antifouling coatings. Biofouling 16 (2-4), 215-224.

Arunkumar, S., Muthuselvam, M., 2009. Analysis of phytochemical constituents and antimicrobial activities of Aloe vera L against cilinical pathogens. World J. Agri. Sci. 5 (5), 572-576.

Bazes, A., Silkina, A., Defer, D., Bernède-Bauduin, C., Quéméner, E., Braud, J.-P., Bourgougnon, N., 2006. Active substances from Ceramium botryocarpum used as antifouling products in aquaculture. Aquaculture $258,664-674$.

Bazes, A., Silkina, A., Douzenel, P., Faÿ, F., Kervarec, N., Morin, D., Berge, J.P., Bourgougnon, N., 2009. Investigation of the antifouling constituents from the brown alga Sargassum muticum (Yendo) Fensholt. J. Appl. Phycol. 10 (1007), 1573-1576.

Bellas, J., 2006. Comparative toxicity of alternative antifouling biocides on embryos and larvae of marine invertebrates. Sci. Total Environ. 367, 573-585.

Bhadury, P., Wright, P.C., 2004. Exploitation of marine algae: biogenic compounds for potential antifouling applications. Planta 219, 561-578.

Bhosale, S.H., Nagle, V.L., Jagtap, T.G., 2002. Antifouling potential of some marine organisms from India against species of Bacillus and Pseudomonas. Mar. Biotechnol. 4, 111-118.

Buma, A.G.J., Sjollema, S.B., van de Poll, W.H., Klamer, H.J.C., Bakker, J.F., 2009. Impact of the antifouling agent Irgarol 1051 on marine phytoplankton species. J. Sea Res. 61, 133-139.

Bushmann, P.J., Ailstock, M.S., 2006. Antibacterial compounds in estuarine submersed aquatic plants. J. Exp. Mar. Biol. Ecol. 331, 141-150. 
Chen, D.J., Feng, D.Q., Yang, Z.W., Wang, Z.C., Qiu, Y., Li, Y.M., 2008. Antifouling metabolites from the mangrove plant Ceriops tagal. Molecules 13, 212-219.

Clare, A.S., 1996. Marine natural product antifoulants: status and potential. Biofouling 9, 211-229.

Dafforn, K.A., Lewis, J.A., Johnston, E.L., 2011. Antifouling strategies: history and regulation, ecological impacts and mitigation. Mar. Pollut. Bull. 62 (3), 453-465.

De Nys, R., Steinberg, P.D., Willemesen, P., Dworjenyn, S.A., Gabelish, C.L., King, R.J., 1995. Broad spectrum effects of secondary metabolites from the red alga Delisea pulchra in antifouling assays. Biofouling 8, $259-271$.

Della Greca, M., Fiorentino, A., Isidori, M., Monaco, P., Zarrelli, A., 2000. Antialgalent-labdane diterpenes from Ruppia maritima. Phytochemistry 55, 909-913.

Devi, P., Solimabi, W., D'Souza, L., Sonak, S., Kamat, Y., Singbal, S.Y.S., 1997a. Screening of some marine plants for activity against marine fouling bacteria. Bot. Mar. 40, 87-91.

Devi, P., Solimabi, W., D'Souza, L., Kamat, S.Y., 1997b. Toxic effects of coastal and marine plant extracts on mosquito larvae. Bot. Mar. 40, 533-535.

Dobretsov, S., Hans-Uwe, Dahms, Qian, P.Y., 2006. Inhibition of biofouling marine microorganisms and their metabolites. Biofouling $22(1), 43-54$.

Floerl, O., Inglis, G.J., Dey, K., Smith, A., 2009. The importance of transport hubs in stepping-stone invasions. J. Appl. Phycol. 46, 37-45.

Fusetani, N., 2004. Biofouling and antifouling. Nat. Prod. Rep. 21, 94-104.

Gillan, F.T., Hogg, R.W., Drew, E.A., 1984. The sterol and fattyacid compositions of seven tropical sea grasses from North Queensland, Australia. Phytochemistry 23, 2817-2821.

Harborne, J.B., Williams, C.A., 1976. Occurrence of sulfated flavonesand caffeic acid esters in members of the Fluviales. Biochem. Syst. Ecol. 4, 37-44.

Harrison, P.G., 1982. Control of microbial growth and of amphipod grazing by water-soluble compounds from leaves of Zostera marina. Mar. Biol. 67, 225-230. 
Harrison, P.G., Chan, A.T., 1980. Inhibition of the growth of microalgae and bacteria by extracts of eelgrass (Zostera marina) leaves. Mar. Biol. 61, 21-26.

Hellio, C., Bourgougnon, N., Le Gal, Y., 2000a. Phenoloxidase (E.C.1.14.18.1) from Mytilus edulis byssus gland: purification, partial characterization and application for screening products with potential antifouling activities. Biofouling 16, 235-244.

Hellio, C., Bremer, G., Pons, A., 2000b. Inhibition of the development of microorganisms (bacteria and fungi) by extracts of marine algae from Brittany (France). Appl. Microbiol. Biotech. 54, 543-549.

Hellio, C., De La Broise, D., Dufossé, L., Le Gal, Y., Bourgougnon, N., 2001. Inhibition of marine bacteria by extracts of macroalgae: potential use for environmentally friendly antifouling paints. Mar. Environ. Res. 52, 231-247.

Hellio, C., Maréchal, J.-P., Da Gama, B.A.P., Pereira, R.C., Clare, A.S., 2009. Natural marine products with antifouling activities. In: Hellio, C., Yebra, D. (Eds.), Advances in Marine Antifouling Coatings and Technologies. Woodhead Publishing Limited, Cambridge, pp. 572-622

Hellio, G., Tsoukou, M., Marechal, J.P., Alfred, N., Beaupoil, C., Clare, A.S., Uagias, C., Roussis, V., 2005. Inhibitory effects of Mediterranean sponge extracts and metabolites on larval settlement of the barnacle Balanus amphitrite. Mar. Biotech. 7, 279-305.

Hema, R., Kumaravel, S., Alagusundaram, K., 2011. GC/MS determination of bioactive components of Murraya koenigii. J. Am. Sci. 7 (1), 80-83.

Hua, K.F., Hsu, H.Y., Su, Y.C., Lin, I.F., Yang, S.S., Chen, Y.M., Chao, L.K.P., 2006. Study on the anti-inflammatory activity of methanol extract from sea grass Zostera japonica. J. Agric. Food Chem. 54, 306-311.

Iyapparaj, P., Ramasubburayan, R., Thulasiraman, R., Narayana Das, J., Pradeep Kumar, V., Palavesam, A., Immanuel, G., 2012. Evidence for the antifouling potentials of marine macroalgae Sargassum wightii. Adv. Nat. Appl. Sci., 6; pp. 153-162.

Iyapparaj, P., Revathi, P., Ramasubburayan, R., Prakash, S., Anantharaman, P., Immanuel, G., Palavesam, A., 2013. Antifouling activity of the methanolic extract of Syringodium isoetifolium, and its toxicity relative to tributyltin on the ovarian development of brown mussel Perna indica. Ecotoxicol. Environ. Saf. 89,231-238. 
Jennings, J.G., Steinberg, P.D., 1997. Phlorotannins versus other factors affecting epiphyte abundance on the kelp Ecklonia radiata. Oecologia 109, 461-473.

Jensen, P.R., Kensin, K.M., Porter, D., Fenical, W., 1998. Evidence that a new antibiotic flavone glycoside chemically defends the sea grass Thalassia testudinum against zoosporic fungi. Appl. Environ. Microbiol. 64, 1490-1496.

Khoobchandani, M., Ojeswi, B.K., Ganesh, N., Srivastava, M.M., Gabbanini, S., Matera, R., lori, R., Valgimigli, L., 2010. Antimicrobial properties and analytical profile of traditional Eruca sativa seed oil: comparison with various aerial and root plant extracts. Food Chem. 120, 217-224.

Konstantinou, I.K., Albanis, T.A., 2004. Worldwide occurrence and effects of antifouling paint booster biocides in the aquatic environment: a review. Environ. Int. 30, 235-248.

Marechal, J.P., Culioli, G., Hellio, C., Thomas-Guyon, H., Callow, M.E., Clare, A.S., Ortalo-Magné, A., 2004. Seasonal variation in antifouling activity of crude extracts of the brown alga Bifurcaria bifurcate (Cystoseiraceae) against cyprids of Balanus amphitrite and the marine bacteria Cobetia marina and Pseudoalteromonas haloplanktis. J. Exp. Mar. Biol. Ecol. 313, 47-62.

Marechal, J., Hellio, C., 2009. Challenges for the development of new non-toxic antifouling solutions. Int. J. Mol. Sci. 10 (11), 4623-4637.

Maximilien, R., De Nys, R., Holmstorm, C., Gram, L., Givskov, M., Crass, K., Kjelleberg, S., Steinberg, P.D., 1998. Chemical mediation of bacterial surface colonization by secondary metabolites from the red alga Delisea Pulchra. Aquat. Microbiol. Ecol. 15,233-246.

Mayavu, P., Sugesh, S., Ravindran, V.J., 2009. Antibacterial activity of seagrass species against biofilm forming bacteria. Res. J. Microbiol. 4 (8), 314-319. McMillan, C., Zapata, O., Escobar, L., 1980. Sulphated phenolic compounds in seagrasses. Aquat. Bot. 8, 267-278.

Meyer, B.N., Ferrigni, N.R., Putnam, J.E., Jacobsen, L.B., Nichols, D.E., McLaughlin, J.L., 1982. Brine shrimp: a convenient general bioassay for active plant constituents. Plant. Med. 45, 31-34.

Murugan, A., Santhana Ramasamy, M.S., 2003. Biofouling detergent natural product from the ascidian Distaplia nathensis. Ind. J. Mar. Sci. 32, 162-164. 
Pawlik, J.R., 1992. Chemical ecology of the settlement of benthic marine invertebrates. Oceanogr. Mar. Biol. Annu. Rev. 30, 273-335.

Peppiatt, C.J., Armstrong, E., Pisacane, T., Burguess, J.G., 2000. Antibacterial activity of resin based coatings containing marine microbial extracts. Biofouling 16 (2-4), 225-234.

Persoone, G., Castritsi-Catharios, J., 1989. A simple bioassay with Artemia larvae to determine the acute toxicity of antifouling paints. Water Res. 23, 893-897.

Poluguerne, E., loannou, E., Georgantea, P., Vagias, C., Roussis, V., Hellio, C., Kraffe, E., Stiger-Pouvreau, V., 2010. Anti-microfouling activity of lipidic metabolites from the invasive brown alga Sargassum muticum (Yendo) Fensholt. Mar. Biotechnol. 12 (1), 52-61.

Prabhadevi, Solimabi, W., DeSouza, L., Kamat, S.Y., 1998. Larvicidal activity of some marine macrophytes against Artemia salina. Adv. Biosci. 17 (2), 75-84.

Prabhakaran, S., Rajaram, R., Balasubramanian, V., Mathivanan, K., 2012. Antifouling potentials of extracts from seaweeds, seagrasses and mangroves against primary biofilm forming bacteria. Asian Pac. J. Trop. Biomed 2 (1), S316-S322.

Premanathan, M., Chandra, K., Bajpai, S.K., Kathiresan, K., 1992. A survey of some Indian marine plants for antiviral activity. Bot. Mar. 35, 321-324.

Qi, S.H., Zhang, S., Yang, L.H., Qian, P.Y., 2008. Antifouling and antibacterial compounds from the gorgonians Subergorgia suberosa and Scripearia gracillis. Nat. Prod. Res. 2, 154-166.

Qian, P.Y., Xu, Y., Fusetani, N., 2010. Natural products as antifouling compounds: recent progress and future perspectives. Biofouling 26 (2), 223-234.

Ragupathi Raja Kannan, R., Arumugam, R., Anantharaman, P., 2012. Chemical composition and antibacterial activity of Indian seagrasses against urinary tract pathogens. Food Chem. 135, 2470-2473.

Ragupathi Raja Kannan, R., Arumugam, R., Iyapparaj, P., Thangaradjou, T., Anantharaman, P., 2013. In vitro antibacterial, cytotoxicity and haemolytic activities and phytochemical analysis of seagrasses from the Gulf of Mannar, South India. Food Chem. 136, 1484-1489. 
Rittschof, D., 2001. Natural products antifoulants and coatings development. In: Mc Clintock, B.J., Baker, B.J. (Eds.), Marine Chemical Ecology. CRC Press, Boca Raton, pp. 543-566

Sanina, N.M., Goncharova, S.N., Kostetsk, E.Y., 2004. Fatty acid composition of individual polar lipid classes from marine macrophytes. Phytochemistry 65, 721-730.

Selvin, J., Lipton, A.P., 2002. Development of a rapid 'Mollusc Foot Adherence Bioassay' for detecting potent antifouling bioactive compounds. Curr. Sci. 83, 735-737.

Silkina, A., Bazes, A., Mouget, J., Bourgougnon, N., L., 2012. Comparative efficiency of macroalgal extracts and booster biocides as antifouling agents to control growth of three diatom species. Mar. Pollut. Bull. 64, 20392046.

Sjogren, M., Dahlstrom, M., Goransson, U., Jonsson, P.R., Bohlin, L., 2004. Recruitment in the field of Balanus improvisus and Mytilus edulis in response to the antifouling cyclopeptides barettin and 8, 9-dihydrobarettin from the marine sponge Geodia baretti. Biofouling 20, 299-312.

Swain, T., 1977. Secondary compounds as protective agents. Annu. Rev. Plant Physiol. 28, 479-501.

Thabard, M., Daoud, G.I., Véron, B., Fletcher, R.L., Hellio, C., 2009. Screening of biological activities of extracts of Ralfsia verrucosa, Petalonia fascia and Scytosiphon lomentaria (Phaeophyceae, Scytosiphonales) for potential antifouling application. Electron. J. Nat. Substan. 4, 1-10.

Todd, J.S., Zimmerman, R.C., Crews, P., Alberte, R.S., 1993. The antifouling activity of natural and synthetic phenolic acid sulfate esters. Phytochemistry 34, 401-404.

Tsouletou, M., Hellio, C., Vagias, C., Harvala, C., Roussis, V., 2002. Chemical defenses and antifouling activity of three mediterranean sponges of the genus Ircinia. Z. Naturforschung 57C, 161-171.

Vergeer, L.H.T., Aarts, T.L., de Groot, J.D., 1995. The 'wasting disease' and the effect of abiotic factors (light intensity, temperature, salinity) and infection with Labyrinthula zosterae on the phenolic content of Zostera marina shoots. Aquat. Bot. 52, 35-44.

Wagh, P., Rai, M., Deshmukh, S.K., Durate, M.T.C., 2006. Bio-activity of oils of Trigonella foenum-graecum an Pongamia pinnata. Afr. J. Biotechnol. 6 (13), 1592-1596. 
Wilsanand, A., Wagh, B., Bapuji, M., 1999. Antifouling activities of marine sedentary invertebrates on some macrofoulers. Ind. J. Mar. Sci. 28, 280-284.

Yayli, N., Gulec, C., Ucuncu, O., Yasar, A., Ulker, S., Coskuncelebi, K., Terzioglu, S., 2005. Composition and antimicrobial activities of volatile components of Minuartia meyeri. Turk. J. Chem. 30, 71-76.

Yebra, D.M., Kill, S., Dam-Job Ansen, K., 2004. Antifouling technology past, present and further steps towards efficient and environmentally friendly antifouling coatings. Prog. Org. Coat. 50, 75-104.

Zhou, X.J., Okamura, H., Nagata, S., 2006. Remarkable synergistic effects in antifouling chemicals against Vibrio fischeri in a bioluminescent assay. J. Health Sci. 52, 243-251. 